\title{
Village-Owned Enterprises (BUM Desa) For Inclusive Growth In Bengkulu Province
}

\author{
Ahmad Soleh \\ \{ahmadsolehse81@yahoo.co.id \\ Economic Faculty, Dehasen University, Bengkulu, Indonesia
}

\begin{abstract}
This study aims to examine the importance of developing Village-Owned Enterprises (BUM Desa) in an effort to achieve inclusive growth in Bengkulu province. The method of approach used in this study is descriptive analysis. The technique of collecting data uses library research. Based on data and phenomena in the field, it shows that Bengkulu province is still experiencing development problems such as rising unemployment, the percentage of poor people is still high and income distribution is not evenly distributed. Most of the population lives in rural areas and depends on the economy in the agricultural sector. Rural-based development is very important to do. BUM Desa is considered as one of the alternative solutions in overcoming rural development problems. Since its establishment in 2015 to 2017, BUM Desa in Bengkulu province has experienced rapid development. Until 2017, BUM Desa totaled 1,032 out of 1,341 villages in nine districts in Bengkulu province. Potential addition of the establishment of BUM Desa by 309. In the long term, the development of BUM Desa is expected to absorb more labor, reduce poverty and more equitable income distribution. Feomena where economic growth contributes to employment, poverty reduction and even distribution of income is known as inclusive growth. This means that the development of BUM Desa needs to be developed as an effort to realize the achievement of inclusive growth in Bengkulu province.
\end{abstract}

Keywords: BUM Desa, Inclusive Growth, Bengkulu Province.

\section{Introduction}

Bengkulu is one of the provinces on the island of Sumatra divided into nine regencies and one city. In 2017, the population in Bengkulu province reached 1,943,269 people consisting of 986,091 male inhabitants and 948,178 female inhabitants. Most of the population is in the district or in rural areas, reaching $80.97 \%$, while the remaining $19.03 \%$ is in the city of Bengkulu. Most of the population works in the agricultural sector, reaching $49.17 \%$. The role of the agricultural sector in the economy of Bengkulu province until 2017 is still very dominant. The position of the agricultural sector as the leading sector of the Bengkulu province is still difficult to shift by other sectors. This phenomenon can be seen from the relatively large role of the agricultural sector in the Bengkulu Province GRDP at current prices compared to other sectors. The nominal value of the GDP of the agricultural sector at current prices in 2017 amounted to 17,729.6 billion Rupiah and its role in the Bengkulu Province GRDP was $29.22 \%$ [1].

Rural-based development[2][3] is very important to do to improve the welfare of most of the population[4]. The number of villages in Bengkulu province in 2017 reached 1,341 in nine 
districts[5][6]. Law Number 6 of 2014 concerning Villages provides an important position for villages to play their role in development. The village government develops village development planning in accordance with its authority by referring to the district development planning[7-9]. Village development is carried out by utilizing local wisdom and village natural resources. Village economy is one of the important factors in assessing the success of village development [10].

The establishment and management of Village-Owned Enterprises (BUM Desa) in the effort to develop village potential and resources can be maximized in order to improve community welfare. The Village Minister's Regulation, Development of Disadvantaged Regions and Transmigration of the Republic of Indonesia Number 4 of 2015 provides certainty of the status of BUM Desa. The establishment of BUM Desa is intended as an effort to accommodate all activities in the economic sector and / or public services managed by the village and / or cooperation between villages. The establishment and management of VillageOwned Enterprises (BUM Desa) is a manifestation of village productive economic management carried out cooperatively, participatory, emancipatory, transparent, accountable, and sustainable, having the main objective is to improve the village economy [5].

The concept and purpose of BUM Desa is in line with efforts to achieve inclusive growth. The concept of inclusive growth is that the community is not only the beneficiary of growth, but also participates and contributes to the growth process [2][11]. Micro, small and medium enterprises (MSMEs) contribute to the achievement of inclusive growth [12]. Various goals or approaches to inclusive growth include increasing employment [9]. Inclusive growth reduces poverty [3] and inclusive growth reduces inequality in income distribution [6]. The development of BUM Desa in Bengkulu Province from 2015 to 2017 tends to increase both from the aspect of business units and the total allocation of funds. Increased performance of BUM Desa is expected to increase production and people's purchasing power. Collaboration between villages is very possible and provides higher profits in the production capacity of goods and services. The increasing economy in all villages and sub-districts will contribute to the economic growth of Bengkulu province. However, the establishment of BUM Desa, which has only been running for three years, is not yet fully at the level of independence. Various problems still occur frequently, so innovation and assistance must be carried out continuously. Based on the above issues, the study of BUM Desa development in realizing inclusive growth in Bengkulu province needs to be done.

\section{Methodology}

The approach used in this study is descriptive analysis. The data collection technique in this study uses the library study method. Library research is a study that emphasizes literature as the object of study, which in this study was carried out by examining existing concepts, theories and data. The data used is secondary data sourced from books, literature, journals, reports and official information from state institutions and accessed through the internet. This study is intended to describe Village-Owned Enterprises (BUM Desa) in relation to achieving inclusive growth in Bengkulu province. With the development of BUM Desa in the entire province of Bengkulu, it is expected that it will increase the production of goods and services, increase employment, reduce poverty and reduce the level of inequality in income distribution. 


\section{Result and Discussion}

This study will present the findings of data and phenomena in the field related to village economic issues, the development of BUM Desa, and the relevance of BUM Desa development in an effort to realize inclusive growth.

\subsection{Village Economic Problems and Solutions for Establishing BUM Desa}

Rural development in developing countries like Indonesia[13], is identical to the issue of poverty alleviation. One example of the problem of poverty is the institution of rural economic governance [4]. One model that is considered effective in building a community economy is by involving the community fully in planning, implementing and evaluating the business activities developed, resulting in an entrepreneurial education process [14]. According to the Regulation of the Minister of Village, Development of Disadvantaged Regions, and Transmigration of the Republic of Indonesia Number 4 of 2015, Participatory Development is a system of development management in villages and rural areas which is coordinated by the village head by promoting togetherness, kinship and mutual cooperation to realize the mainstreaming of peace and social justice [8]. Law Number 6 of 2014 concerning Villages encourages the establishment of independent, democratic and prosperous villages [15]. Furthermore, the Regulation of the Village Minister, Development of Disadvantaged Regions and Transmigration of the Republic of Indonesia Number 4 of 2015 provides certainty of the status of BUM Desa.

The establishment and development of BUM Desa is considered as one of the solutions in overcoming various economic problems that arise in rural areas. The establishment of BUM Desa is based on an analysis of the potential and development of the village economy. Some economic problems, especially in rural areas include (a) Low land tenure and relatively small scale of business and even tend to be subsistence; (b) Limited capital access; (c) Lack of market access and low bargaining value; (d) Lack of knowledge about good methods of production; (e) Facilities and infrastructure have not supported production inputs, production processes, and post-production.

In an effort to empower village communities, village assistance needs to be done. Village Minister Regulation, Development of Disadvantaged Areas, and Transmigration Number 3 of 2015, regulates village assistance. Village assistance is an activity to carry out community empowerment actions through assistance, organizing, directing and facilitating the village [7]. The purpose of village assistance in this Ministerial Regulation includes (a) Increasing the capacity, effectiveness and accountability of village government and village development; (b) Increasing village community initiatives, awareness and participation in participatory village development; (c) Increasing the synergy of inter-sectoral village development programs; and (d) Optimizing village assets locally in an emancipatory manner.

\subsection{Development of Village-Owned Enterprises (BUM Desa) in Bengkulu Province}

Village-owned enterprises (BUM Desa) in Bengkulu province were established in 2015. Until 2017, the number of BUM Desa in Bengkulu province was 1,032. Whereas there are 1,341 villages in 117 sub-districts. This shows that not all villages in Bengkulu province have BUM Desa. There are only two districts where all villages have BUM Desa, namely Rejang Lebong and Kepahiang Regencies. The development of BUM Desa can be seen from the 
aspects of the development of BUM Desa business units and the development of the total allocation of funds every year.

\section{a. Development of Business Units}

Since 2015-2017, the BUM Desa business unit in Bengkulu province has tended to develop. The BUM Desa business unit in Bengkulu province has currently amounted to six business units, namely service business units, agriculture and plantations, livestock and fisheries, trade, industry, and tourism. The service business unit is the dominant business unit in BUM Desa in Bengkulu province which reaches $71.4 \%$. The most service business units are in Muko muko regency, which is 123 . Next is the trading business unit which reaches $18.7 \%$. The most trading business units are in Kepahiang district, which is 54 . While the business units that are still managed by BUM Desa are tourism business units, which are $1.1 \%$. Kepahiang is the district that manages the most tourism business units, namely 5. Rejang Lebong Regency has the most business units for agricultural and plantation businesses and livestock and fisheries business units, namely 39 and 20. Whereas Lebong district has the most business units for industrial business units, namely a number of 5 . This business unit will continue to grow because there are still 309 villages that until 2017 do not have BUM Desa.

\section{b. Development of Total Found Allocation}

The development of BUM Desa can also be seen from the use of Village Funds for BUM Desa activities every year. The allocation of the use of Village Funds for BUM Desa activities in Bengkulu province from 2015-2017 experienced a significant increase as shown in figure 1.

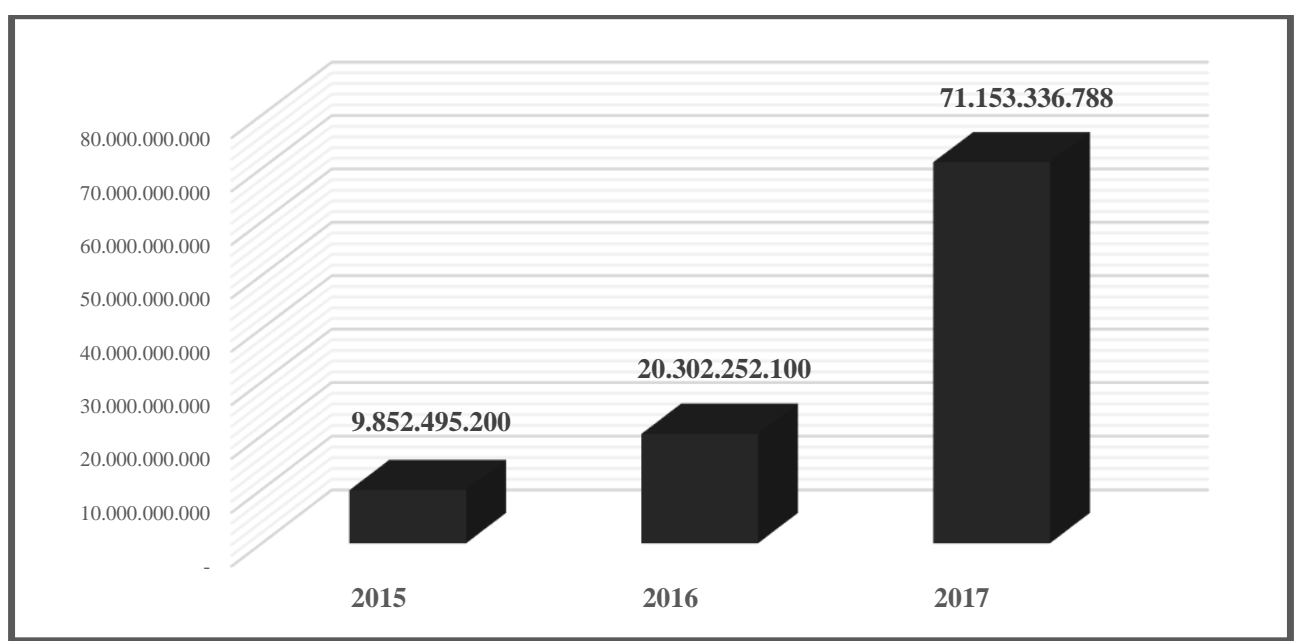

Fig. 1. Allocation of Village Funds for BUM Desa Activities in Bengkulu Province

Figure 1 explains that in 2015, which was the initial year of the establishment of BUM Desa, the total allocation of Village Funds used for BUM Desa was IDR 9,852,495,200. The total funds were used for capital participation in the amount of Rp 789,234,530, -, investment (grants) in the village amounting to Rp. 8,868,760,670, - and the formation and training of Rp. $194,500,000$. In 2016, the total allocation of Village Funds used for BUM Desa increased by 
$106 \%$ or a total of Rp. $20,302,252,100$. The total funds were used for capital participation in the amount of Rp. 15,725,527,812, -, the investment (grant) of the village was Rp. $994,252,700$, - and the formation and training amounted to Rp. 3,582,471,588. In 2017, the total Village Fund allocation used for BUM Desa amounted to Rp 71,153,336,788, - or an increase of $250.47 \%$ from the previous year. The total funds are used for capital participation in the amount of Rp. 50,920,268,880, - technical and training guidance amounting to Rp. 3,294,240,633, -, the establishment of BUM Desa amounted to Rp 2,885,688,040, - building construction amounting to $\mathrm{Rp} 7,594,740,020$ and investment (village grants) amounting to $\mathrm{Rp}$ $6,458,399,215,-$

The allocation of funds for 2015 is mostly used for investment (grants) in villages, namely in the South Bengkulu district. At the beginning of the year, there were only three districts that had established BUM Desa, namely South Bengkulu district, Kaur and Muko muko. Whereas in the second year, only one district was Lebong district which had not yet established BUM Desa. The allocation of funds in the second year was mostly for equity participation which reached $77.46 \%$. Likewise in 2017 , the allocation of funds was mostly used for capital participation, which reached $71.56 \%$ in nine districts in Bengkulu province

\subsection{Village-Owned Enterprises (BUM Desa) For Achieving Inclusive Growth}

The purpose of establishing BUM Desa according to the Village Minister's Regulation, Development of Disadvantaged Regions and Transmigration of the Republic of Indonesia Number 4 of 2015 is (a) to improve the village economy; (b) optimizing village assets so that they are beneficial for the welfare of the village; (c) increasing community efforts in managing village economic potential; (d) develop plans for business cooperation between villages and or with third parties; (e) creating market opportunities and networks that support the public service needs of citizens; (f) opening employment; (g) improve the welfare of the community through improving public services, growth and equitable economic village; and (h) increasing the income of the village community and Village Original Income [8].

The context of the establishment of BUM Desa is expected to be the driving force of the village economy, which means that the establishment of BUM Desa is not only an orientation to profit, but the essence is the establishment of being able to provide economic and social benefits to the villagers [10]. BUM Desa as a pillar of rural economic activities, functions as a social and commercial institution [13]. One model that is considered effective in building a community economy is by involving the community fully in planning, implementing and evaluating the business activities developed, resulting in an entrepreneurial education process [14].

The concept and purpose of establishing BUM Desa is in line with the concept of achieving inclusive growth. Based on literature studies, it can be conveyed that the second concept is a pattern of development that involves all stakeholders. The community not only receives benefits from the results of development, but actively participates in the implementation of development. The purpose of the establishment of BUM Desa is also in line with the inclusive growth approach, namely growth that is able to absorb more workers, reduce poverty and reduce the level of inequality in income distribution. The BUM Desa framework in relation to achieving inclusive growth is shown in Figure 2. Figure 2 explains that the development of BUM Desa with various units of business activities as a whole in the long term is expected to have a positive impact on employment. Increasing people's income is expected to increase welfare and reduce poverty. In addition, this also has the potential to reduce inequality in income distribution. 


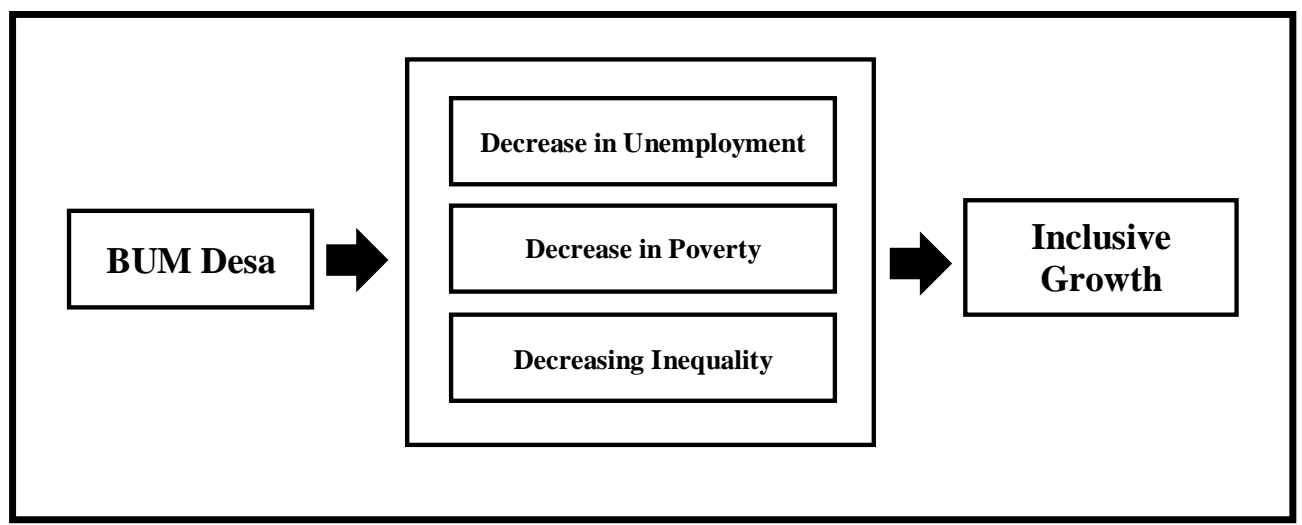

Fig. 2. BUM Desa Framework for Achieving Inclusive Growth

In the long term, the independence of BUM Desa has become one of the indicators of the success of the village economy that is managed jointly. In Bengkulu Province, BUM Desa still has the potential to be developed. The development includes the establishment of BUM Desa in 309 villages that have not yet been formed. Development can also be done by increasing the diversity of business activity units. Village economic growth through increased production of goods and services will encourage macroeconomic growth. Statistical data shows that the economic growth of Bengkulu province from 2015-2017 experienced fluctuations with an average of $5.14 \%$ per year. Placing the position of Bengkulu province as the third largest ranking in the average economic growth in the island of Sumatra after the provinces of West Sumatra and Lampung. The average growth is also higher than the national average economic growth of $4.99 \%$ per year.

The work force in Bengkulu province in 2015-2017 experienced fluctuations. The decline in the workforce occurred in 2017, namely from 997,913 people to 969,255 people. Most of the population who work are in the agricultural sector and are in rural areas. In 2017, the agricultural sector absorbs $49.17 \%$ of the workforce. While unemployment data shows that in 2017 there was an increase from the previous year, from 32,942 people to 36,279 . This shows that there is a need to provide more jobs to accommodate residents who do not have jobs. Poverty is still one of the problems of development in Bengkulu province. Although the data shows that the poverty trend in 2015-2017 has decreased. In 2015, the percentage of poor people was $17.16 \%$. Furthermore, in 2016 the percentage of poor people fell to $17.03 \%$ and declined again in 2017, amounting to $15.59 \%$. Increased income and community welfare are expected to reduce the level of inequality in the income distribution of the community. From 2015-2017, inequality in the income distribution of Bengkulu province tended to be evenly distributed. This is indicated by the gini ratio which tends to decrease. The average gini ratio of Bengkulu province is 0.36 .

The development of BUM Desa in the long term is expected to absorb more workers, especially for communities in rural areas. Most of the population is in rural areas that depend on livelihoods in the agricultural sector. The high absorption of labor is expected to increase income and purchasing power of the people. Thus, in the long run poverty can continue to decline. Furthermore, rural development that is evenly distributed in all rural areas will be able to reduce development inequality through equitable income distribution. Such economic conditions, where economic growth has an impact on increasing employment, reducing 
poverty and increasing income equity are known as inclusive growth which has developed more or less in the last two decades.

\section{Conclussion}

Based on the discussion in the previous section it can be concluded:

a) Bengkulu Province is still experiencing development problems including unemployment, poverty and inequality in income distribution. Most of the population lives in rural areas and depends on the economy in the agricultural sector. So it needs rural-based development.

b) BUM Desa is considered as one of the alternative solutions in overcoming development problems in rural areas. The development of BUM Desa has progressed very rapidly both when viewed from the aspects of business activity units and from the total aspects of the allocation of funds used. Development can also be done by optimizing the establishment of BUM Desa in all districts. From 2015-2017 the number of BUM Desa in Bengkulu province was 1,032 out of 1,341 villages in nine districts. So, there are still the potential of establishing 309 BUM Desa in Bengkulu province.

c) The development of BUM Desa in the long term is expected to increase village economy, the value of production of goods and services, and the people's purchasing power. Increased variety of business activities are expected to absorb more labor and reduce unemployment. Increased welfare through increased income is expected to reduce poverty. Equitable development in all rural areas is expected to reduce the level of inequality in income distribution. Feomena where economic growth contributes to employment, poverty reduction and even distribution of income is known as inclusive growth. This means that the development of BUM Desa needs to be developed as an effort to realize the achievement of inclusive growth in Bengkulu province.

\section{References}

[1] BPS-Statistic of Bengkulu Province. (2018). "Bengkulu Province In Figures 2018”. Bengkulu, BPS-Statistic of Bengkulu Province.

[2] Haan, Arjan De. (2013). "Inclusive Growth: More than Safety Nets". International Development Research Centre. SIG Working Paper 2013(1): 1-16.

[3] Habito, Cielito F. (2009). "Patterns of Inclusive Growth in Developing Asia: Insights from an Enhanced Growth-Poverty Elasticity Analysis". Asian Development Bank Institute (ADBI) working paper series No. 145, 1-55.

[4] Hardijono, Rachmat., et al. (2014). "Economic Independence Of The Village Through Institutional Village Enterprises (BUMDes)". Journal of Economics and Finance 3(2): 21-30.

[5] Hidayati, Umi. (2015). "Performance Analysis of Village-Owned Enterprise Managers as a Basic of Designing Education and Training”. European Journal of Business and Management 7(32): 143-147.

[6] Klasen, Stephan. (2010). "Measuring and Monitoring Inclusive Growth: Multiple Definition, Open Questions, and Some Constructive Proposals". Manila: Asian Development Bank. Working Paper Series, 12, 1-15.

[7] Village Minister Regulation, Disadvantaged Regional Development, and Transmigration Number 3 of 2015 concerning Village Assistance. 
[8] Regulation of the Minister of Village, Development of Disadvantaged Regions, and Transmigration of the Republic of Indonesia Number 4 of 2015 concerning Establishment, Management and Management, and Dissolution of Village-Owned Enterprises.

[9] Samans, Richard., Blanke, Jennifer., Corrigan,Gemma., and Drzeniek, Margareta. (2015). “The Inclusive Growth and Development Report 2015". Geneva: World Economic Forum.

[10] Setyobakti, Moh. Hudi. (2017). "Identification Of Business Enterprises BUMDes Based On Social And Economic Aspect (Case Study At Bumdes Ijen Lestari Tamansari Village District Of Banyuwangi)". Jurnal Ilmiah Bidang Akuntansi dan Manajemen 14(2): 101-110.

[11] Shyni,V. K. and Mavoothu, D. (2014). "Financial Inclusion -The Way Towards Inclusive Growth". International Journal of Advanced Research, 2(2): 649-655.

[12] Srinivas, K. T. (2013). "Role of Micro, Small and Medium Enterprises in Inclusive Growth". International Journal of Engineering and Management Research, 3(4): 57-61.

[13] Srirejeki, Kiky. (2018). "Empowering the role of village owned enterprises (BUMDes) for rural development: case of Indonesia". Journal of Accounting, Management, and Economics 20(1): 510.

[14] Suastika, I. Nengah. (2017). “Village Enterprises (A Case Study Of Rural Enterprise-Based Social Capital At The Purwakerti Village Community)". South East Asia Journal of Contemporary Business, Economics and Law 12(4): 26-29.

[15] Law of the Republic of Indonesia Number 6 of 2014 concerning Villages 